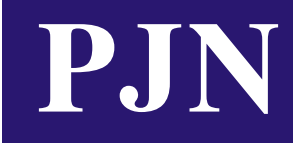

ISSN 1680-5194

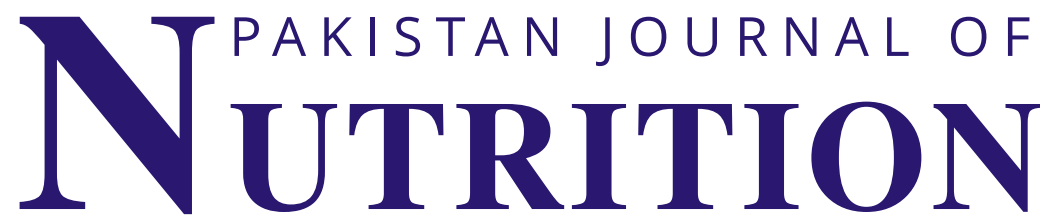

ANSI迫e佔

308 Lasani Town, Sargodha Road, Faisalabad - Pakistan Mob: +92 3003008585 , Fax: +92 418815544

E-mail: editorpjn@gmail.com 


\title{
Short Communication Production of an Instant Functional Beverage Made from Ciplukan (Physalis angulata L.) With Cassia vera
}

\author{
Fauzan Azima, Novelina, Inda Suryanti and Daimon Syukri \\ Department of Agricultural Product Technology, Faculty of Agricultural Technology, Andalas University, 25163 Padang, \\ West Sumatera, Indonesia
}

\section{Abstract}

Objective: This study was designed to evaluate the physicochemical and sensory properties of an instant functional beverage which was formulated using ciplukan plant as the main material with Cassia vera powder. Materials and Methods: The experiment consisted of five treatments which were as follows: (A) $2 \%$, (B) $4 \%,(C) 6 \%$, (D) $8 \%$ and (E) $10 \%$ of ciplukan whereas the composition of Cassia vera and sucrose were constant. The antioxidant capacity, chlorophylls and physalin content were evaluated for raw materials. The appearance, soluble time, insoluble part, moisture content, ash content and a sensory test were conducted for the resulting products. Results: All raw materials were containing the beneficial compounds that indicated by positive results for antioxidant activity, chlorophyll and physalin. Based on sensory test, the product derived from formula C (ciplukan powder $0.6 \mathrm{~g}$ and Cassia vera $0.2 \mathrm{~g}$ ) indicated as the most acceptable product with average value of insoluble parts $(1.07 \%)$, soluble time $(16.62 \mathrm{sec})$, water content $(0.76 \%)$, ash content $(0.86 \%)$, physalin (++), antioxidant activity (39.63\%) and chlorophyll content (6.67\%). Conclusion: The production of ciplukan powdered beverage with addition of Cassia vera had improved functionality, practicality and consumers acceptance of existing ciplukan-derived beverage.

Key words: Ciplukan, Cassia vera, instant functional beverage production, liquid, powdered
Received: January 05, 2018
Accepted: April 10, 2018
Published: June 15, 2018

Citation: Fauzan Azima, Novelina, Inda Suryanti and Daimon Syukri, 2018. Production of an instant functional beverage made from ciplukan (Physalis angulata L.) with Cassia vera. Pak. J. Nutr., 17: 355-360.

Corresponding Author: Fauzan Azima, Department of Agricultural Product Technology, Faculty of Agricultural Technology, Andalas University, 25163 Padang, West Sumatera, Indonesia

Copyright: @ 2018 Fauzan Azima etal. This is an open access article distributed under the terms of the creative commons attribution License, which permits unrestricted use, distribution and reproduction in any medium, provided the original author and source are credited.

Competing Interest: The authors have declared that no competing interest exists.

Data Availability: All relevant data are within the paper and its supporting information files. 


\section{INTRODUCTION}

The demand for functional foods and beverages has increased in many countries all over the world. The different approaches have been conducted in order to develop the functional foods and beverages such as exploitation of microorganism functionality, optimization of the production and formulation of novel functional beverages, use of prebiotics and synbiotics, use and processing of natural ingredients and use of by-products of fruit and food industries as functional ingredients ${ }^{1}$. Nowadays an increasing trend in global society is green consumerism, that is consumer interest and focus toward natural products, where the use of synthetic additives is limited. Natural products have been used since ancient times and in folklore for the treatment of many diseases and illnesses. One of these natural products is a plant called ciplukan (Physalis angulata, L.). Ciplukan is one of Indonesian local plant which classifies as a herbaceous annual plant of the family Solanaceae ${ }^{2}$. Ciplukan has been known as a natural resource that contains saponins, flavonoids, polyphenols and physalin ${ }^{3}$. Especially, physalin is as an active compound contributes to inhibit the growth of cancer cells $s^{4}$. In practically, all parts of ciplukan plant such as leaves, fruits, stems and roots were used for functional beverage in liquid form. However, this existing product has some limitations such as limited shelf life, undesirable aroma and bitter taste ${ }^{2}$.

The existing functional liquid ciplukan beverage has a short shelf life due to high moisture content. This condition indicates a high water activity which leads the quality loss in products by increasing the enzyme activity and microbial growth. Therefore, the reducing moisture content in a product is considered for extending the shelf life. Drying is an ancient technique to preserve food products by remove moisture content. There are many drying techniques that have invented, among of them is spray drying. Dehydration by spray drying is used in the wide range of products in food industries to produce dry powders. In this study, the production of powdered ciplukan beverage was attempted in order to develop a functional ciplukan beverages that has long shelf life and easy to serve. Since ciplukan delivered bitter taste and unpleasant aroma, combination with another natural product which has good taste and aroma was also considered in production of ciplukan-derived beverages. Cassia verawas proposed as an additive ingredient since it has high content of antioxidant with good characterisitics. It was noted that adding Cassia vera in pegagan instant powder beverage gave a good result on sensory properties ${ }^{5}$. Therefore, the objective of this study was to evaluate the physicochemical and sensory properties of an instant functional beverage which was formulated using ciplukan plant as the main material with Cassia vera powder.

\section{MATERIALS AND METHODS}

The ciplukan (whole plant) was obtained from the area Aia Dingin Lubuk Minturun, West Sumatera and Cassia vera and sucrose were obtained from traditional market in Padang City, West Sumatera, Indonesia. This research was conducted at laboratory of Department of Agricultural Product Technology, Andalas University, Padang, West Sumatera, Indonesia.

Preparation of ciplukan and Cassia vera powder: The extract of ciplukan and Cassia vera were obtained by the maceration process using 70\% ethanol and $96 \%$ ethanol for $20 \mathrm{~h}$, respectively. Each crude extract obtained was then evaporated using a rotary evaporator (Eyela, Japan) and powdered by the addition of maltodextrin using a spray dryer (Armfield, UK). The production of instant functional beverage was following the formula in Table 1.

Observations: The determination of antioxidant activity using 2,2-Diphenyl-2-picrylhydrazyl (DPPH) method, physalin content (qualitative-Liebermen-Buchard test) and chlorophyll content (spectrophotometry) were conducted for both raw materials and the resulting products. The appearance, soluble time, insoluble part, moisture content, ash content and a sensory test were conducted for the resulting products.

Statistical analysis: All the analyses were replicated at least three times. Statistical analysis was performed with SPSS (Software version 15) using one way ANOVA. Duncan multiple range test was carried out to compare the mean values for samples with significant differences taken at $p<0.05$.

Table 1: Experimental design for functional beverage formula Treatments

\begin{tabular}{llllll} 
Material (g) & A & B & C & D & E \\
\hline Ciplukan powder & 0.2 & 0.4 & 0.6 & 0.8 & 1 \\
Cassia vera powder & 0.2 & 0.2 & 0.2 & 0.2 & 0.2 \\
Sucrose & 10 & 10 & 10 & 10 & 10 \\
\hline
\end{tabular}




\section{RESULTS AND DISCUSSION}

There are many steps to obtain phytochemicals from plant such as milling, grinding, homogenization and extraction. Among these steps, extraction is the main step for recovering and isolating phytochemicals as beneficial compounds from plant materials. Extraction efficiency is affected by the chemical nature of phytochemicals, the extraction method used, sample particle size, the solvent used as well as the presence of interfering substances ${ }^{6}$. Ethanol extraction is reported as a suitable condition in extraction of phytochemical in plant material especially for food application ${ }^{7}$. Moreover, the combination of ethanol and water could enhance the efficacy of phytochemical extraction. Therefore, based on researchers preliminary results on extraction efficacy of beneficial compounds in ciplukan and Cassia vera (data not shown), $70 \%$ ethanol and $90 \%$ ethanol were choosen as an optimum condition for the extraction of phytochemicals in ciplukan and Cassia vera plants, respectively.
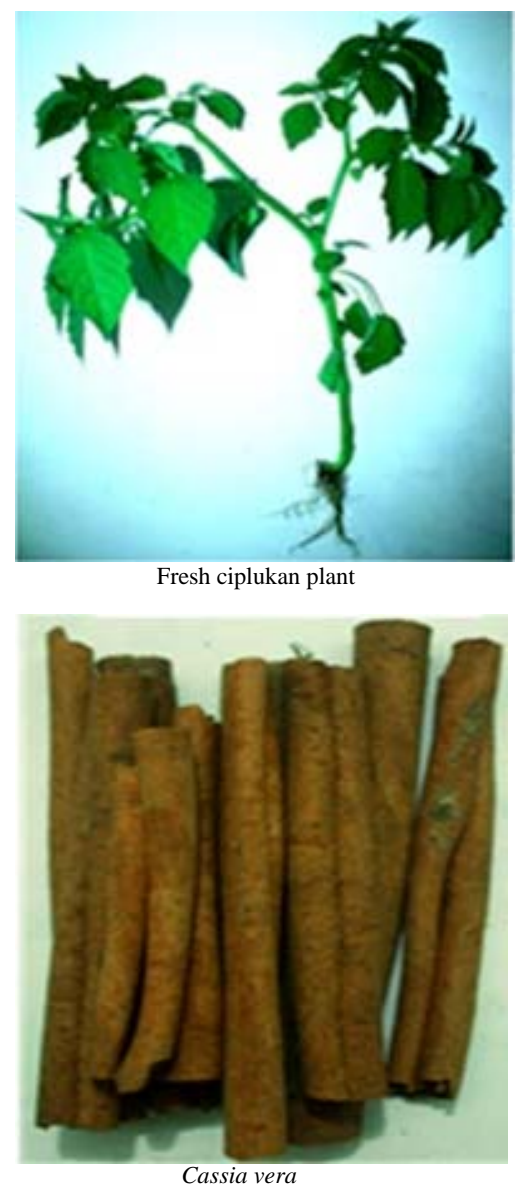

Ciplukan and Cassia vera contained many beneficial compounds that can be characterized as antioxidants. Table 2 shows that Cassia vera powder at $1000 \mathrm{mg} \mathrm{L}^{-1}$ solution has higher antioxidant capacity compared to ciplukan powder while physalin was obviously detected in ciplukan. Based on these results, it can be suggested that Cassia vera as an additive ingredient was powerful to improve bioactivity of the physalin. Currently, a large variety of natural resources were utilized for enriching the diversity of ingredients for functional food production in Indonesia, especially in West Sumatera ${ }^{9}$, therefore, combination of ciplukan and Cassia vera as materials for foods and beverages is also promising to be developed further.

Figure 1 and 2 indicate the picture of raw materials, intermediate and resulting product of a functional beverage

Table 2: Information of nutritional compounds in ciplukan and Cassia vera

\begin{tabular}{lcc}
\hline Parameters & Ciplukan & Cassia vera \\
\hline Antioxidant (\%) & 13.33 & 36.76 \\
Physalin & + & - \\
Chlorophyll $\left(\mathrm{mg} \mathrm{L}^{-1}\right)$ & 15.54 & - \\
\hline
\end{tabular}

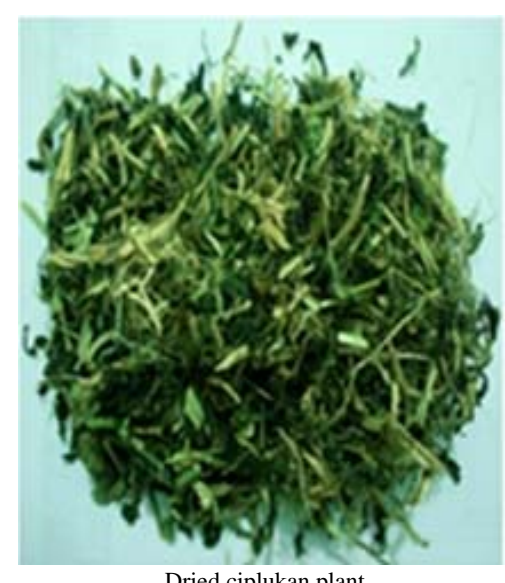

Dried ciplukan plant

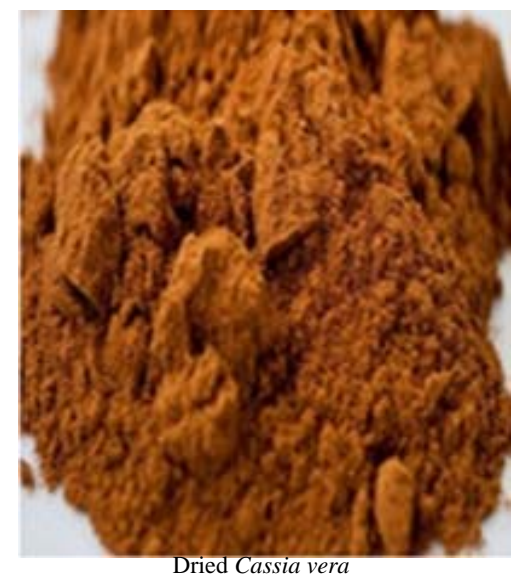

Fig. 1: Materials of ciplukan and Cassia vera 


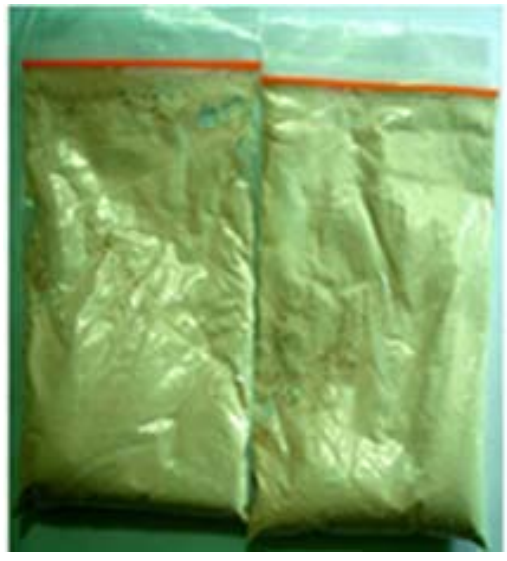

Spray dried of Cassia vera+ maltodextrin

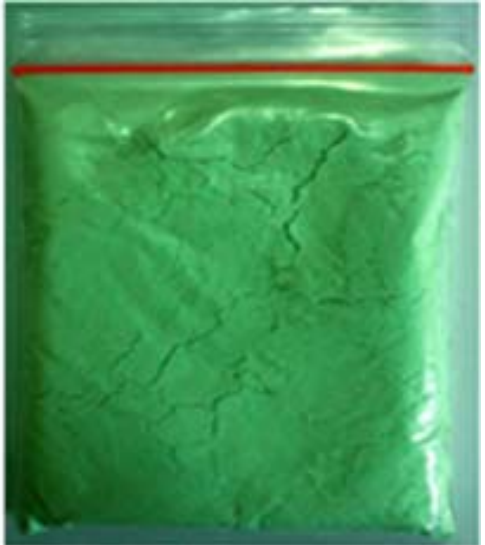

Spray dried of ciplukan+ maltodextrin

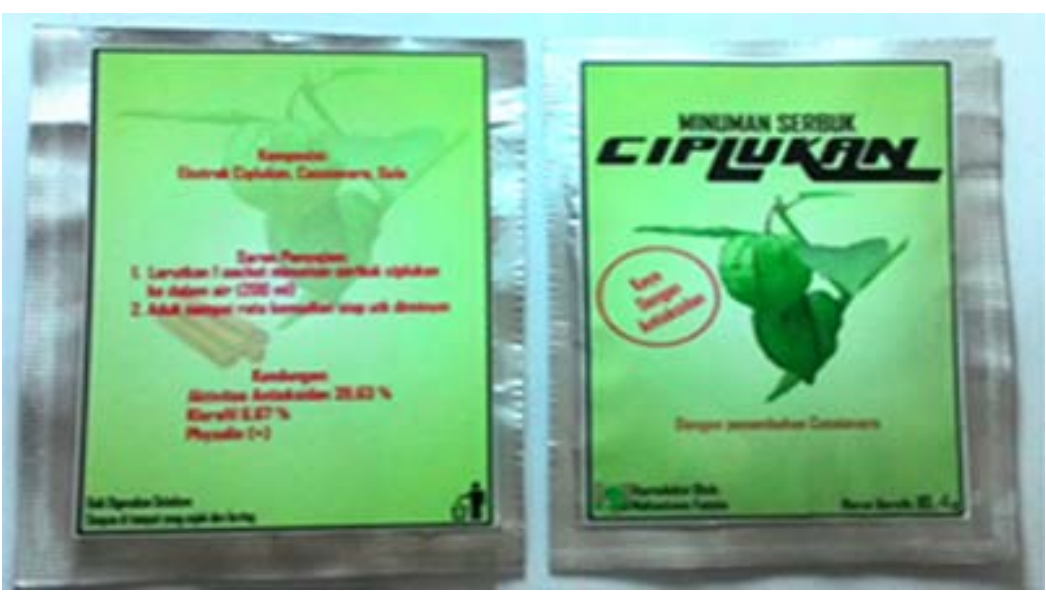

Final product

Fig. 2: Intermediate and final product of functional beverage made from ciplukan and Cassia vera

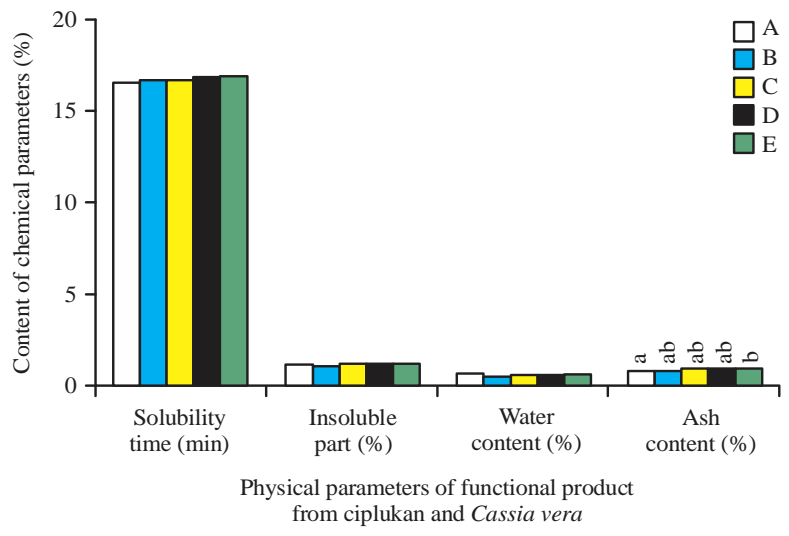

Fig. 3: Physical characteristics of functional beverage product from ciplukan and Cassia vera

made from ciplukan and Cassia vera powder. Results of the present study indicated that Cassia vera could reduce the original green color of ciplukan and suggested it becoming an attractive thing for consumer with the presence of bright color.
Figure 3 shows physical parameters such as soluble time, insoluble parts, water content and ash content of resulting product. No significant difference was observed among each parameter except on ash content. In development of an instant functional beverage, physical parameters such as product solubility time in water, insoluble parts and water content are crucial since these parameters could indicate physical quality of the product. Product solubility time and insoluble parts influence product practicality. Ciplukan concentration affected the ash content of the products. Since ash content has a correlation with the presence of minerals ${ }^{10}$, hence, ash content could also reflect the nutritional value of the product. It can be suggested that the abundance of chlorophyll in ciplukan increased minerals content in treated products. According to Soetan et al. ${ }^{11}$, magnesium that classified as a beneficial mineral for human could be derived from plant's chlorophyll.

Figure 4 shows antioxidant activity and chlorophyll content of the resulting products. Results of the present study indicate that increasing ciplukan concentration affected the 


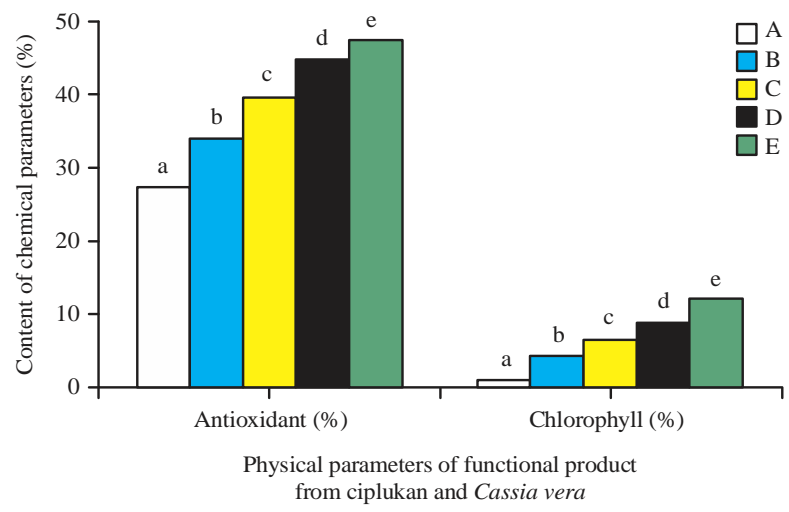

Fig. 4: Chemical characteristics of functional beverage product from ciplukan and Cassia vera

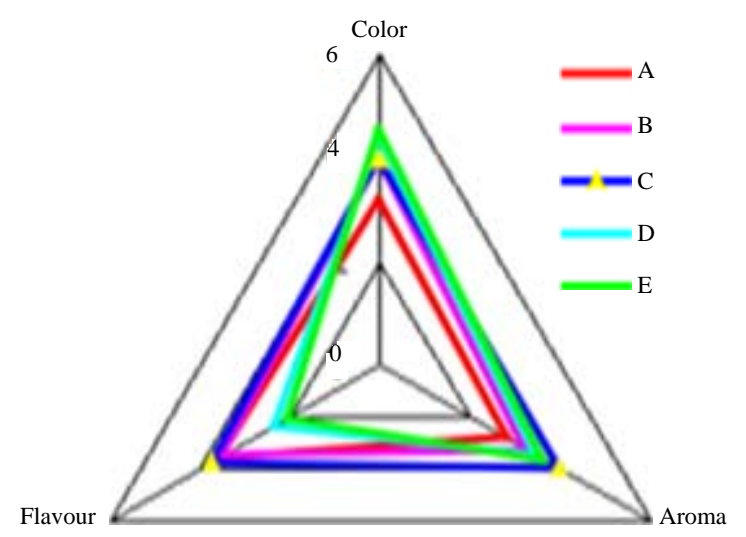

Fig. 5: Sensory analysis of functional product from ciplukan and Cassia vera

antioxidant activity, chlorophyll content and physalin content (data not shown) of the resulting products. The presence of chlorophylls, physalin and other beneficial compounds in ciplukan and Cassia vera are responsible for increment of antioxidant capacity of the resulting products. Substantial evidence indicates that food containing high antioxidants is important for human health such as disease prevention ${ }^{12}$.

Since the main problem of functional beverage made from ciplukan was undesirable characteristics such as unpleasant aroma and bitter taste, the effect of Cassia vera addition on consumers acceptance was observed by organoleptic sensory analysis. Figure 5 indicates the radar chart of organoleptic sensory test, including analyses of color, aroma and taste, the resulting product. It shows that formula $\mathrm{C}$ was the most acceptable product with average acceptance value of color, aroma and flavor were 3.9, 3.9 and 3.7 , respectively. Results of the current study indicate that there is an optimum combination of ciplukan and
Cassia vera in order to produce a good quality product based on consumers acceptance. The use of Cassia vera with an appropriate ciplukan composition has successfully reduced the undesirable characteristics of ciplukan. Abundance of essential oils in Cassia vera reduced undesirable aroma and bitter taste of ciplukan.

According to Lestari ${ }^{13}$, ciplukan has been consumed as liquid for years in Indonesia. To authors knowledge, consumers dislike ciplukan due to its undesirable aroma and bitter taste when it is consumed as liquid and there is no development of powdered ciplukan beverages till date. In this study, a powdered beverage that derived from ciplukan was successfully produced and also improved the consumer acceptance of the product by the addition of Cassia vera. The use of Cassia vera in the production of functional beverage has been developed in many products such as instant pegagan ${ }^{5}$, instant coffee and ginger beverages ${ }^{14,15}$ and make it as a popular additive ingredient for healthy products. In agreement with present study results, the addition of Cassia vera could give positive impact to the quality and economic value of the resulting products.

\section{CONCLUSION}

Utilizing all natural ingredients for the production of functional food products make the consumer comfortable and satisfied with the taste and functionality of ingredients. This is the key idea that will set this product apart from the existing form. The production of ciplukan powdered beverage with addition of Cassia verahad improved functionality, practicality and consumers acceptance of existing ciplukan-derived beverage. This product is required for enrichment of foods and beverages diversity in Indonesia.

\section{SIGNIFICANCE STATEMENT}

This study discovers the possible synergistic effect of ciplukan and Cassia vera powder in order to produce an alternative functional beverage in West Sumatera province, Indonesia. This study will provide preliminary data that can use for researchers to further improve this product for a better human health.

\section{REFERENCES}

1. Corbo, M.R., A. Bevilacqua, L. Petruzzi, F.P. Casanova and M. Sinigaglia, 2014. Functional beverages: The emerging side of functional foods. Compr. Rev. Food Sci. Food Saf., 13: 1192-1206. 
2. Hadisaputra, F.F., 2008. Uji sitotoksik ekstrak etanol kultur akar ciplukan (Physalis angulata) yang ditumbuhkan pada media murashige-skoog dengan peningkatan konsentrasi sukrosa terhadap sel myelema. Under Garduate Thesis, Faculty of Pharmacy, Muhammadiyah University of Surakarta, Surakarta.

3. Shingu, K., S. Yahara, H. Okabe and T. Nohara, 1992. Three new withanolides, physagulins $\mathrm{E}, \mathrm{F}$ and $\mathrm{G}$ from Physalis angulate L. Chem. Pharma. Bull., 40: 2448-2451.

4. Chiang, H.C., S.M. Jaw and P.M. Chen, 1992. Inhibitory effects of physalin $B$ and physalin $F$ on various human leukemia cells in vitro. Anticancer Res., 12: 1155-1162.

5. Anggia, M., 2011. Pembuatan minuman instan pegagan (Centella asiatica) dengan sita rasa Cassia vera. Master Graduate Thesis, Faculty of Agricultural Technology, Andalas University, Indonesia.

6. Stalikas, C.D., 2007. Extraction, separation and detection methods for phenolic acids and flavonoids. J. Sep. Sci., 30: 3268-3295.

7. Syukri, D., D. Darwis and A. Santoni, 2014. Major anthocyanin pigments in the Ficus padana fruits: HPLC-DAD-ESI-MS identification and antioxidant activity. Indonesian J. Chem., 14: 297-303.

8. Do, Q.D., A.E. Angkawijaya, P.L. Tran-Nguyen, L.H. Huynh, F.E. Soetaredjo, S. Ismadji and Y.H. Ju, 2014. Effect of extraction solvent on total phenol content, total flavonoid content and antioxidant activity of Limnophila aromatica. J. Food Drug Anal., 22: 296-302.
9. Azima, F., Neswati, D. Syukri and D. Indrayenti, 2016. Utilization of mixed oyek cassava, corn grits, brown rice and soy grits in the production of snack extrusion. Res. J. Pharm. Biol. Chem. Sci., 7: 1063-1069.

10. Winarno, F.G., 1997. Kimia Pangan Dan Gizi. PT Gramedia Pustaka Utama Press, Jakarta, Indonesia, (In Indonesian).

11. Soetan, K.O., C.O. Olaiya and O.E. Oyewole, 2010. The importance of mineral elements for humans, domestic animals and plants: A review. Afr. J. Food Sci., 4: 200-222.

12. Alam, M.N., N.J. Bristi and M. Ra quzzaman, 2013. Review on in vivo and in vitro methods evaluation of antioxidant activity. Saudi Pharm. J., 21: 143-152.

13. Lestari, D.A., 2014. Pengaruh penggunaan basis hidrokarbon, serap dan kombinasi terhadap kualitas fisik salep ekstrak maserasi daun ciplukan (Physallis angulata Linn). E-J. Politeknik Tegal, 2: 1-3.

14. Rohmah, M., 2009. Study of physical chemistry and sensory properties of coffee robusta (Coffea cannephora), cinnamon (Cinnamomun burmanii) and its mixture. J. Teknol. Pertan., 4: 75-83.

15. Firdausni, Failisnur and Y.H. Diza, 2011. Potency of Cassia vera pigment in ginger drink instant as a functional drink. J. Litbang Industri, 1: 15-21. 